\title{
PERDAGANGAN LADA DI JAMBI ABAD XVI-XVIII
}

\section{PEPPER TRADING IN JAMBI FROM THE 16TH TO THE 18TH CENTURY}

\author{
Dedi Arman \\ Balai Pelestarian Nilai Budaya Kepulauan Riau \\ Jln. Pramuka No. 7, Tanjungpinang \\ deasutanmakmur79@gmail.com
}

Diterima tanggal 8 Januari 2018

Disetujui tanggal 28 Juni 2018

\begin{abstract}
This paper discusses the trade of Jambi pepper covering production, production, transportation, marketing from upstream to downstream and involved actors of the whole trade. Trade route is divided into two. First, from upstream production area brought downstream (Port of Jambi). Secondly, from upstream through alternative path to Muaro Tebo to Strait of Malacca through Indragiri and Kuala Tungkal. The traders involved the main producer of pepper in Jambi. Producers of pepper, Minangkabau farmers living along the Batanghari River, and traders are Portuguese, Chinese, Dutch, and English, as well as the sultan and nobles of Jambi. The heyday of Jambi pepper trade did not last long as pepper farmers moved to plant other commodities, such as rice and cotton especially when the price of pepper fell in the world market.
\end{abstract}

Keywords: trading, pepper, and Jambi Sultanate.

\begin{abstract}
Abstrak
Naskah ini membahas tentang perdagangan lada Jambi yang meliputi wilayah produksi, produksi, transportasi, pemasaran dari hulu ke hilir dan aktor-aktor yang terlibat dari keseluruhan perdagangan. Jalur perdagangan dibagi dua, Pertama, dari daerah produksi di hulu dibawa ke hilir (Pelabuhan Jambi). Kedua, dari hulu melalui jalur alternatif ke Muaro Tebo menuju Selat Malaka melalui Indragiri dan Kuala Tungkal. Adapun pelaku perdagangan melibatkan produsen utama lada di Jambi. Produsen lada, petani Minangkabau yang tinggal di sepanjang Sungai Batanghari, dan pedagang adalah Portugis, Cina, Belanda, dan Inggris, maupun sultan dan bangsawan Jambi. Masa kejayaan perdagangan lada Jambi tidak bertahan lama karena petani lada beralih menanam komoditas lain, seperti padi dan kapas terlebih ketika harga lada anjlok di pasaran dunia.
\end{abstract}

Kata kunci: perdagangan, lada, dan Kesultanan Jambi. 


\section{A. PENDAHULUAN}

Pelayaran dan perdagangan rempah Sumatra adalah aspek historis yang relatif terabaikan oleh sejarawan. Belum ada sebuah kajian khusus yang membincangkan fenomena historis itu (Gusti Asnan, 2017: 1). Kalau pun ada, pembahasan aspek rempah hanya menjadi bagian dari aspek dan fokus kajian lain. Menurut Gusti Asnan, tidak diragukan lagi, pelayaran dan perdagangan rempah pernah menjadi bagian penting dari sejarah Sumatra. Tidak hanya itu, pelayaran dan perdagangan rempah Sumatra berpengaruh besar dalam jaringan pelayaran dan perdagangan Nusantara dan jaringan global.

Lada adalah salah satu komoditas perdagangan unggulan dari wilayah Nusantara, khususnya Sumatra. Permintaan akan lada di pasar Eropa dan Timur Tengah begitu tinggi membuat daerah-daerah penghasil lada dapat menaikkan harga jual dan wilayah produksinya meluas. Pencarian rempah membuat para penjelajah Eropa mengarungi lautan pada abad ke-16. Lada memiliki banyak fungsi, seperti bumbu masakan, pengawet, obatobatan dan diambil minyaknya untuk wewangian serta dapat digunakan sebagai alat tukar layaknya uang. Pada saat ini lada banyak digunakan sebagai bumbu masakan. Peningkatan permintaan lada berkaitan dengan munculnya kebiasaan hidup sehat (Masroh, 2014: 64).

Salah satu daerah penghasil lada di Sumatra pada abad ke-16 adalah Jambi.
Para penguasa Jambi memanfaatkan pertumbuhan perdagangan di Perairan Malaka pada 1550-an hingga akhir abad ke-17, Kesultanan Jambi melakukan perdagangan lada yang menguntungkan. Pada awalnya dengan Portugis dan sejak 1615 dengan dengan perusahaan dagang Inggris dan Hindia Timur Belanda. Dalam perdagangan lada ini juga terlibat orang-orang Cina, Melayu, Makassar dan Jawa (Scholten, 2008:43).

Scholten mengutip Barbara Watson Andaya menulis, pada tahun 1616, ibu kota Jambi sudah dipandang sebagai pelabuhan terkaya kedua di Sumatra setelah Aceh. Menurut perkiraan Kompeni Hindia Timur Belanda (Vereenigde Oost Indische Compagnie atau VOC), kesultanan meraih keuntungan 30-35 persen dari lada yang terjual. Jambi berperan aktif dalam percaturan politik internasional daerah itu. Tahun 1670-an keperkasaannya sebanding dengan tetangga sekaligus musuhnya, Palembang dan Johor (Scholten, 2008: 44).

Di Jambi, lada dihasilkan oleh daerah hulu Jambi seperti Tanjung, Kuamang, Sumai, Muara Tembesi, dan daerah lainnya di VII Koto. Daerahdaerah ini secara politik lebih dikuasai Minangkabau ketimbang Jambi. Jalur perdagangan lada di Jambi tidak hanya dari hulu ke hilir Jambi, tapi juga memiliki jalur alternatif. Lada dari hulu dan Minangkabau dikirim ke Selat Malaka melalui Muaro Ketalo yang sering disebut dengan Malaka Kecil. Lada kemudian dibawa lewat sungai ke 
Sungai Indragiri dan menyeberang ke pantai timur Sumatra (Lindayanti, et al., 2001: 67).

Topik ini menarik untuk diteliti karena dari begitu banyaknya wilayah penghasil lada di wilayah Sumatera, Jambi pernah menjadi pelabuhan terbesar kedua di Sumatra setelah Aceh dengan lada sebagai komoditas ekspor utama. Aktivitas perdagangan lada di Jambi tersebut mengalami pasang surut dan persaingan monopoli perdagangan yang menarik untuk dikaji. Apalagi, Jambi hanya berfungsi sebagai bandar dagang sebelum lada diekspor ke Cina, Eropa, maupun dikirim ke Banten. Selain itu, perdagangan lada di Jambi yang mengalami kemunduran dan bahkan menghilang sehingga kejayaannya di masa lalu nyaris tidak ditemukan jejaknya hingga sekarang.

Artikel "Perdagangan Lada di Jambi Abad ke-16 hingga 18" ini adalah pengembangan dari tulisan pendek yang penulis tulis di laman kajanglako.com tanggal 11 September 2017 dan diposting ulang di laman kebudayaan.kemdikbud.go.id/ bpnbkepri 13 September 2017. Berbagai data yang didapatkan, ditampilkan, dan dibahas dalam artikel ini lebih luas dan lengkap dari yang ditampilkan di laman ini.

Terkait pustaka, berdasarkan penelusuran penulis, belum ada buku atau laporan penelitian yang mengkaji perdagangan lada di Jambi secara spesifik. Meskipun demikian, perdagangan lada di Jambi telah disinggung dalam buku Barbara Watson
Andaya (2016), Hidup Bersaudara, Sumatra Tenggara Pada AbadXVII dan XVIII. Buku ini jadi rujukan utama penulis untuk mengambarkan tipe masyarakat Jambi yang terbagi atas kelompok hulu dan hilir. Kondisi ini juga berpengaruh pada perdagangan lada di Jambi. Lada ditanam di hulu dan bandar dagangnya di hilir atau di Pelabuhan Jambi.

M.A.P. Meilink Roelofsz (2016) dalam bukunya Perdagangan Asia \& Pengaruh Eropa di Nusantara Antara 1500 dan Sekitar 1630 juga memaparkan adanya perdagangan lada di Jambi mulanya dikendalikan oleh Portugis ketimbang bangsa Eropa lain. Portugis yang paling duluan masuk Jambi. Persaingan terjadi belakangan setelah Inggris dan Belanda datang. Persaingan tersebut berakhir dengan terusirnya Portugis dari Jambi.

Buku Lindayanti, Junaidi T. Noor, dan Ujang Hariadi (2013), Jambi Dalam Sejarah 1500-1942 menulis tentang perubahan perekonomian Jambi. Mulai dari Jambi sebagai pelabuhan ekspor bagi produk daerah pedalaman Minangkabau, seperti emas, lada, dan produk hutan Jambi sendiri dan komoditas karet dan kelapa sawit setelah Jambi berada di bawah kekuasaan pemerintahan kolonial Belanda hingga belakangan ditemukan minyak bumi.

Tulisan A.B. Lapian(1992) berjudul Jambi Dalam Jaringan Pelayaran dan Perdagangan Masa Awal telah mengupas perdagangan di Jambi pada masa zaman pra-sejarah, 
zaman Sriwijaya hingga munculnya Belanda melalui VOC di Jambi. Dalam tulisan ini adanya perdagangan lada di Jambi yang mendorong kedatangan orang Makassar, Jawa dan daerah lainnya ke Jambi untuk berdagang.

Adanya perdagangan lada di Jambi pada abad XVI-XVII ditulis Anastasia Wiwik Swastiwi (2010) dalam bukunya Jambi Dalam Lintasan Sejarah Melayu (Abad I-XVII). Swastiwi menyebutkan, jauh sebelum kedatangan Belanda tahun 1615, Jambi sudah menjadi penghasil utama lada, emas, pinang, gaharu, getah alam merah, getah jernang, dan getah jelutung. Menginjak awal abad ke-17, Jambi ramai dikunjungi pedagang dari Cina, India, Parsi, Arab, Portugis, Inggris dan Belanda. Pedagang Inggris dan Portugis duluan datang, tapi tidak diizinkan membuka kantor dagangnya di Jambi. Sama dengan buku yang lain, informasi tentang perdagangan lada menjadi bagian kecil dari keseluruhan buku. Tidak dijelaskan secara panjang lebar mengenai aktivitas perdagangan lada, termasuk daerah-daerah penghasil lada dan jalur perdagangan lada di Jambi.

Dalam bukunya, Elsbeth LocherScholten (2008), Kesultanan Sumatra dan Negara Kolonial: Hubungan Jambi- Batavia dan Bangkitnya Imperialisme Belanda (1830-1907), menjelaskan tentang hubungan antara Kesultanan Jambi dan Batavia. Buku ini juga menerangkan wilayah Kesultanan Jambi dan kehidupan sosial ekonomi pada masa kesultanan. Locher-Scholten juga menyinggung daya tarik emas terhadap imigrasi dari Minangkabau yang memberikan warna keanekaragaman penduduk Jambi.

Pustaka lain yang khusus membahas kaitan perdagangan lada di Jambi dan perantau ke Jambi adalah Harmoni Kehidupan di Provinsi Multi Etnis: Studi Kasus Integrasi Antara Penduduk Pendatang dan Penduduk Asli di Jambi karya Lindayanti, Witrianto dan Zulqayyim (2010). Mereka menyampaikan bahwa perdagangan lada merupakan salah satu faktor utama pendatang, diantaranya orang Minangkabau, Bugis, Arab, Cina, dan suku-suku lainnya di Indonesia hijrah ke Jambi.

William Marsden (2013) dalam buku Sejarah Sumatra juga menulis produksi flora Sumatra sebagai komoditas perdagangan. Menurut Marsden, komoditas yang paling penting dan berlimpah dari semua komoditas perdagangan di Sumatra adalah lada. Namun, ia lebih banyak membahas soal teknis budidaya lada dan beragam jenisnya. Selain itu, ia juga membahas perdagangan yang dilakukan East India Company (EIC), kantor dagang Inggris.

Tak hanya soal lada Jambi, sebagai perbandingan juga melihat perdagangan lada di daerah lain. Perdagangan lada di Lampung ditulis Iim Imadudin berjudul Perdagangan Lada di Lampung Dalam Tiga Masa (16531930) (Imadudin, 2016: 349). Tulisan ini mengungkap dinamika perdagangan lada di Lampung dalam tiga sistem politik. Perebutan pengaruh di kawasan 
tersebut tercipta dalam pola dominasi dan subordinasi. Lampung sebagai penghasil lada berada dalam pengaruh Banten, VOC, dan pemerintah Hindia Belanda. Dengan demikian, tidak terhindarkan berlangsungnya eksploitasi ekonomi di dalam hubungan tersebut. Hasil penelitian memperlihatkan bahwa dinamika perdagangan lada di Lampung tidak terlepas dari berbagai pihak yang bersaing. Para pemainnya adalah Kesultanan Banten, VOC, dan pemerintah Hindia Belanda. Namun, tidak dapat dikesampingkan peranan elite lokal Lampung. Memudarnya perdagangan lada, selain karena faktor internal, seperti tidak optimalnya pemeliharaan kebun lada, juga disebabkan menurunnya permintaan dari pasar internasional. Faktor monopoli perdagangan lada oleh kekuatan asing turut menghancurkan sistem perdagangan lada yang telah berlangsung cukup lama.

Tulisan ini berbeda dengan tulisantulisan sebelumnya karena fokus memaparkan aktivitas perdagangan lada di Jambi pada abad ke-16 hingga 18. Ini berbeda dengan tulisan sebelumnya yang sedikit menyinggung tentang aktivitas perdagangan lada. Misalnya Barbara Watson Andaya juga membahas tentang perdagangan merica (lada) di Jambi, tapi hanya sebagian kecil. Namun, bukunya memfokuskan pada kehidupan dua bersaudara dan persaingan antara Jambi dan Palembang.
Berdasarkan uraian sebelumnya, penulis merumuskan beberapa permasalahan, yakni: 1) Bagaimana jalur perdagangan lada di Jambi abad XVI-XVIII?; 2) Kelompok sosial dan siapa saja yang berperan dalam perdagangan lada?; 3) Bagaimana perkembangan perdagangan lada di Jambi dalam kurun waktu tersebut?; 4) Faktor- faktor apa yang menyebabkan perdagangan lada mengalami kemunduran?

Penelitian ini menggunakan metode penelitian sejarah yang meliputi heuristik, kritik internal dan eksternal, interpretasi, dan historiografi. Pada tahap heuristik atau pengumpulan data, peneliti terlebih dahulu menentukan topik yang akan dibahas yaitu perdagangan lada. Pengumpulan data berupa studi kepustakaan dilakukan di Arsip Nasional Republik Indonesia, Dinas Kebudayaan dan Pariwisata Jambi, Badan Perpustakaan, dan Arsip Provinsi Jambi.

Tahap selanjutnya yaitu kritik internal dan eksternal, untuk melihat keaslian dan reliabilitas sumber yang didapatkan. Kritik eksternal yang dilakukan oleh peneliti dilakukan dengan melihat latar belakang dari penulis, kertas yang digunakan, jenis huruf, bahasa, ejaan, dan penerbit dari sumber buku. Kritik internal dilakukan dengan melihat isi dari buku itu, apakah isinya relevan dengan fakta sejarah dan sesuai dengan topik yang akan dibahas. Tahap selanjutnya interpretasi, dilakukan berdasarkan fakta dan juga data yang diperoleh sehingga tidak 
hanya imajinasi semata untuk itu peneliti mencantumkan sumber data yang digunakan.

Pada tahap interpretasi sumbersumber primer yang telah didapatkan dibandingkan sumber-sumber lain baik sekunder ataupun tersier. Hal ini dilakukan agar tidak ada kesalahan pemaknaan. Pada tahap ini peneliti berupaya untuk mengaitkan antara fakta yang satu dengan fakta lainnya, sehingga diperoleh sebuah gambaran peristiwa secara utuh dan kronologi serta saling berkaitan. Tahap terakhir historiografi yaitu penulisan sejarah. Penulisan sejarah disusun secara kronologis.

\section{B. HASIL DAN BAHASAN}

\section{Asal Muasal Lada di Nusantara}

Komoditas yang paling penting dan berlimpah dari semua komoditas perdagangan di Sumatra adalah lada (Marsden, 2008: 151). Tanaman lada ditemukan hampir di seluruh pelosok Sumatra. Ada tiga kawasan penghasil lada di Sumatra pada awal kedatangan bangsa Eropa awal abad XVI-XVIII. Pertama, kawasan pesisir sebelah utara pantai barat Sumatra (Barus, Singkil dan Meulaboh). Kedua, kawasan bagian selatan pesisir barat Sumatra meliputi Indrapura, Bengkulu, dan Lampung. Ketiga, kawasan bagian tengah dan selatan bagian timur Pulau Sumatra. Adapun Jambi, Aceh, Pedir, dan Palembang masuk kelompok bagian ketiga. Wilayah penghasil lada tersebut disebut dengan istilah pepergebied dan pelabuhannya dinamakan peperhaven dalam literatur Belanda (Asnan, 2017:

4).

Lada liar yang belum diolah dari Sumatra dan Jawa telah sejak lama dijual ke Cina sebelum kedatangan bangsa Eropa di abad XVI. Salah satu jenis lada, yaitu kemukus telah dikenal sebagai barang ekspor dari Palembang dan Jambi dan jadi primadona di pasar Cina dan Nusantara pada abad ke- 8 (Andaya, 2016: 80). Lada spesies Pipe nigrum bukan berasal dari Nusantara, melainkan dari barat daya India. Lada jenis ini tidak tumbuh alami melainkan dibudidayakan.

Lada merupakan salah satu jenis rempah yang sudah dikenal sejak zaman dahulu kala. Kegunaan lada pada zaman dulu tidak hanya untuk perasa dan penambah rasa pada makanan tetapi juga untuk menunjukkan status sosial seseorang. Di Eropa pada abad pertengahan, jamuan makan yang disajikan dengan taburan lada menunjukkan status sosial orang yang menyantapnya. Sementara di Mesir Kuno, lada hitam digunakan sebagai salah satu bahan dalam proses pembalseman atau pengawetan mayat (http://jalurrempah.com, diakses pada 14 September 2017).

Menurut Andaya, budidaya lada di Sumatra dimulai abad XV. Pedagang India yang memperkenalkan lada saat bertemu pedagang Sumatra di Malaka. Kedatangannya begitu lambat, tapi lada berkembang pesat dalam waktu tidak begitu lama. Lada hitam begitu menarik karena salah satu faktornya tidak memerlukan lahan yang subur dan 
curah hujan lebih dari 2500 milimeter per tahun. Dengan demikian, lada sangat cocok dengan iklim pedalaman Sumatra. Tanaman lada dapat tumbuh subur di daerah dataran rendah dan berada di dekat sungai atau mata air (Andaya, 2016:80).

Pada abad ke-17, lada tumbuh sebagai komoditas perdagangan paling menguntungkan yang didatangkan Kepulauan Nusantara (Banten dan Sumatra) ke Cina. Memasuki abad ke16, perdagangan lada di Cina bergeser ke Pelabuhan Banten (Soedewo, 2007:18). Dalam tulisannya itu, Soedewo menyebutkan, pada masa itu, Banten menjadi pusat perdagangan Asia. Setiap tahun sekitar 1.500 ton lada diekspor dari Banten ke Cina. Selain ke Cina, negara-negara Eropa secara rutin juga mengimpor lada dari Banten ratarata 3.000 ton per tahun. Lada pertama kali dibawa para pedagang Arab dan Persia dan kemudian ditanam di sekitar Banten. Dari Banten, tumbuhan itu lalu dikembangkan di sekitar Jawa Tengah dan Jawa Timur. Namun, karena hasilnya kurang bagus, lada kemudian dibawa ke seberang pulau di Sumatra. Di sana, lada tumbuh subur dan bisa dikembangbiakkan menjadi berbagai macam varietas baru.

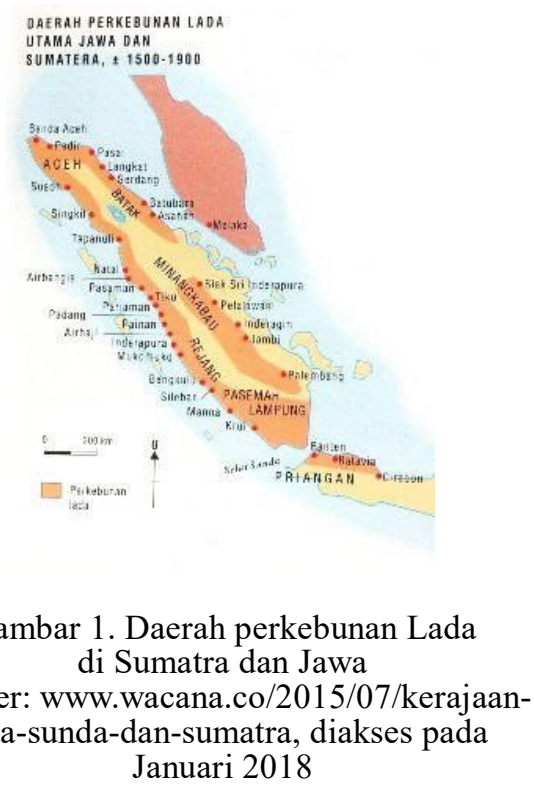

Di Sumatra bermunculan varietasvarietas lada yang menunjukkan namanama tempat, seperti Aceh, Kerinci, Jambi. Varietas-varietas ini juga bisa ditemukan di Bangka, Kalimantan Barat, hingga Sarawak di Malaysia. Meski berkembang pesat di Sumatra dan beberapa daerah lain, sisa kejayaan perkebunan lada di Banten nyaris sirna. Hal yang sama juga berlaku di Jambi.

\section{Lada Jambi}

Jambi adalah salah satu kesultanan terkecil di Sumatra hingga abad ke-19. Wilayahnya membentang 350 kilometer dari timur ke barat, 220 kilometer dari utara ke selatan. Wilayah Jambi berbatasan dengan Keresidenan Palembang di sebelah selatan, Kesultanan Indragiri dan sejumlah kerajaan merdeka Minangkabau, seperti Siguntur dan Lima Kota di sebelah utara, dan sebelah barat pegunungan Bukit Barisan, Jambi berbatasan dengan dataran tinggi Minangkabau 
(Locher-Scholten, 2008: 39). Jambi berkembang di cekungan sebuah sungai yang memiliki banyak anak sungai. Batanghari adalah sungai terpanjang di Sumatra berkelok-kelok sepanjang 800 kilometer menjadi tulang punggung wilayah itu. Anak-anak sungainya ada Tembesi (dengan anak sungainya Merangin) dan makin ke hulu ada Sungai Tabir, Tebo, serta Jujuhan.

Lada Jambi adalah salah satu jenis atau varian lada di Sumatra pada abad XVI sampai XVIII. Varian lainnya adalah lada manna dan lada kkawur. Penamaan lada itu berdasarkan asal usul lada. Lada kkawur itu dikenal sebagai lada Lampung. Jenis lada terkuat atau lada yang memiliki ketahanan terhadap cuaca memiliki buah dan daun yang paling besar. Pertumbuhannya lebih lambat dari lada manna tapi berdaya tahan lebih lama. Daun dan buah lada manna lebih kecil dan unik. Lada manna lebih cepat panen tetapi tidak bertahan lama. Adapun lada Jambi reputasinya paling jelek. Daun dan buahnya pun berukuran paling kecil, berumur paling pendek dan sulit dipasang tiang penyangga dalam penanamannya (Marsden dalam Arman, 2017).

Di beberapa tempat lain di Sumatra hanya dikenal 2 jenis lada, yakni lada sulur dan lada anggur. Sebutan lada sulur dan lada anggur bukanlah berdasarkan spesiesnya melainkan dari cara penanamannya. Lada sulur ditanam dari potongan-potongan rambat, sedangkan lada anggur ditanam secara berlapis. Musim panen tanaman lada pada abad XV sampai XVIII tidak menentu. Hal ini mungkin disebabkan oleh periode monsun (iklim yang dipengaruhi oleh pergantian arah angin). Meskipun demikian, panen lada umumnya terjadi dua kali dalam setahun. Periode pertama disebut pupul agung antara bulan Oktober sampai Maret, sedangkan kedua disebut buah selo antara April hingga September. Kadang di beberapa tempat, hasil panen akan dikumpulkan sedikit-sedikit sepanjang tahun. Ada juga keseluruhan hasil produksi didapat dalam sekali panen (Marsden dalam Arman, 2017).

Di Jambi, lada dihasilkan oleh daerah hulu Jambi seperti Tanjung, Kuamang, Sumai, Muara Tembesi, dan daerah lainnya di VII Koto. Produsen utama lada di Jambi adalah orangorang Minangkabau yang tinggal di sepanjang Sungai Batanghari, khususnya di dua distrik yaitu Tanjung dan Kuamang, federasi Kota Tujuh (VII Koto) dan Sembilan Kota (IX Koto). Tom Pires menyebutkan sejak awal abad XVI, Jambi dikenal sebagai penghasil emas dan mungkin hal inilah yang mendorong orang Minangkabau datang ke VII Koto dan IX Koto. Lada juga ditanam di aliran sungai Muaro Ketalo dan sepanjang aliran sungai Tembesi (Andaya, 2016: 89). 
3. Perdagangan Lada: Jalur dan Perkembangannya

\subsection{Jalur dan Pola Utama} Perdagangan

Lada di Jambi dihasilkan oleh daerah hulu. Menurut Barbara Watson Andaya, konotasi ulu (hulu) tidak hanya mengacu pada hulu sungai, tapi juga pada masyarakat dan gaya hidup yang berbeda dengan penghuni ilir (hilir). Lebih luas lagi, perbedaan ini dapat merujuk pada perbedaan lingkungan fisik dan ekonomi. Hulu dicirikan dengan jumlah titik-titik perdagangan yang berkembang dipersimpangan sungai-sungai penting, seperti Muaro Tebo. Pusatpusat perdagangan ini dihubungkan oleh jalur-jalur darat ke Minangkabau dan pesisir barat. Sementara, daerah hilir yang merupakan pusat kesultanan adalah pusat aktivitas perdagangan. Lokasi perdagangan berada tidak jauh dari Istana Kota Pilih yaitu di pelabuhan ekspor di mana terletak sungai kecil menuju Sungai Batanghari. Pada akhir abad XVI, daerah hulu Sungai Batanghari dinyatakan sebagai daerah rantau (daerah migrasi) orang Minangkabau. Dalam berpuluh-puluh tahun setelahnya, arus rantau orang Minangkabau ke hulu Sungai Batanghari semakin intensif. Para perantau Minangkabau ini melangsungkan kawin campur dengan penduduk asli. Di daerah tertentu, dominasi kebudayaan mereka terlihat hingga abad ke XIX (Andaya, 2016: 37).
Sebelum kedatangan bangsa Eropa, jaringan hubungan ekonomi antara para petani lada di hulu dan pelabuhan di hilir hubungannya tidak kuat. Keadaan geografis membuat pemaksaan kontrol kekuasaan oleh hilir tidak bisa berjalan. Para penduduk pedalaman akan berbondong-bondong datang ke hilir untuk menjual hasil dagangannya jika yakin akan mendapat perlakukan yang adil.

Pada awal abad XVI, petani lada di hulu Jambi menjual ladanya ke hilir. Dari sana, pedagang besar lada mengangkut lada ke pelabuhan yang lebih besar dari Jambi, yakni Palembang, Banten, Gresik, dan juga Pattani di semenanjung Malaya. Selama 60 tahun lebih, sebagian besar lada produksi Jambi tidak dijual ke hilir Jambi melainkan dijual ke pelabuhan yang populer di mata pedagang Cina. Dampaknya adalah aktivitas perdagangan di Jambi masih kurang ramai dibandingkan tetangganya yaitu Palembang (Andaya, 2016: 82).

Pola perdagangan lada di Jambi umumnya berupa petani lada yang berlayar ke hilir menjual lada mereka. Namun, pedagang Inggris, Belanda ataupun pihak Kesultanan Jambi yang tidak mau menunggu begitu saja kedatangan petani lada telah membentuk pola perdagangan lain. Mereka mengirimkan agen ke hulu untuk membeli lada langsung dari petani. Agen itu lebih banyak orang Cina ketimbang orang Eropa langsung. Orang Cina lebih bisa membaur dengan 
masyarakat hulu sebagai penghasil lada.

Orang Cina yang jadi agen ke hulu membawa bekal tekstil, seperti kain untuk dijual di hulu. Kadang lada dibarter dengan tekstil tersebut. Tidak jarang juga, agen itu meminjamkan uang kepada petani lada. Pola perdagangan ini diikuti para pemain lada, termasuk bangsawan Jambi yang juga pemain lada di Jambi (Lindayanti, et al., 2013: 68).

Kira-kira 60 perahu kecil pergi ke hulu untuk mengumpulkan lada dalam setiap tahunnya. Mereka datang antara akhir Maret dan awal April setelah musim penghujan berakhir. Mereka juga datang setelah menghadiri panen raya yang dilaksanakan bulan Oktober. Para petani lada dari hulu muncul di Pelabuhan Jambi antara November dan Desember. Mereka membawa rakit. Setiap rakit berisi 150 pikul. Setiap tahunnya diperkirakan 40.000 sampai 50.000 karung lada dari hulu Jambi dibawa ke hilir Jambi dan ada juga melalui Sungai Indragiri (Andaya, 2016: 89).

Pengiriman lada sering terganggu karena kesulitan akses geografis antara hulu dan hilir. Penundaaan sering berbulan-bulan karena rakit hanya bisa melewati sungai dalam kondisi air sungai tinggi. Saat kondisi sungai dangkal, pelayaran dari hulu berhenti setelah melewati Sungai Tembesi. Pada kondisi normal, petani lada di hulu yang membawa hasil ladanya ke hilir Jambi. Bangsa Eropa tidak sabar dengan kondisi ini karena hasil perdagangan yang minim.

Pada abad XVI hingga abad XVIII, kebergantungan pada alam berupa arus laut dan angin monsun sangat tinggi. Aktivitas pelayaran sangat ditentukan kondisi alam. Hal ini disebabkan sarana transportasi masih berupa kapal dan perahu yang masih menggunakan layar dan bentuknya masih sederhana. Beberapa sumber menyebut bahwa ada beberapa model dan bentuk kapal dan perahu yang ada di Sumatra, termasuk Jambi pada zaman itu. Ada 25 jenis kapal atau perahu. Sebagian memiliki bentuk dan model yang sangat sederhana dan ukurannya kecil (Asnan, 2017: 3).

Lada umumnya dibawa dengan menggunakan rakit yang kadang dibuat dari kayu gelondongan. Namun, paling sering dibuat dengan bambu. Untuk menjaga agar muatan kering dibuat dudukan khusus dari potongan bambu. Rakit dikayuh dari bagian depan dan belakang dengan dayung di sungaisungai yang beraliran kencang. Para pengayuh rakit harus menggunakan tenaga ekstra pada kondisi air yang meluncur deras. Banyak pula tantangan dalam mengangkut lada dengan rakit ke hilir, seperti banyaknya pepohonan di sungai (Marsden, 2013: 167).

Ada perahu yang terbuat dari sebatang kayu yang dilubangi berukuran panjang tiga atau empat meter yang digunakan di sungai. Hanya bisa membawa satu atau dua penumpang dengan beberapa kilogram barang. Beberapa jenis kapal yang 
sangat populer di Sumatra zaman itu adalah lanchara (lancing), kapal layar, wangkang, perahu, sampan, jung, sekuner, top, dan cunia (Asnan, 2017: 7).

William Marsden menyebut di sungai yang sempit, lada umumnya dibawa dengan menggunakan rakit yang kadang dibuat dari kayu gelondongan. Namun, paling sering dibuat dari bambu. Untuk menjaga agar muatan kering dibuat dudukan khusus dari potongan bambu. Rakit dikayuh dari bagian depan dan belakang dengan dayung di sungai-sungai yang beraliran kencang. Para pengayuh rakit harus menggunakan tenaga ekstra pada kondisi air yang meluncur deras. Banyak pula tantangan dalam mengangkut lada dengan rakit ke hilir, seperti banyaknya pepohonan di sungai. Banyak juga bebatuan besar yang bisa megahancurkan rakit (Marsden, 2013: 167).

Lada yang dikirim ke hilir sampai di tujuan disimpan di gudang penyimpanan. Ada juga langsung dinaikkan ke kapal-kapal orang Eropa atau kapal pembeli yang telah menunggu. Syahbandar lah paling berkuasa di Pelabuhan Jambi dalam proses ekspor atau pengiriman lada ke luar Jambi. Pada eranya Portugis, Cina, Belanda dan Inggris, syahbandar pelabuhan dipercayakan pada orang Tionghoa (Lindayanti, 2013: 66).

\subsection{Jalur Perdagangan Alternatif}

Jaringan pelayaran dan perdagangan rempah di Jambi pada era awal meliputi dua bentuk utama. Pertama, sebagaimana yang telah dijelaskan sebelumnya, jaringan hulu (pedalaman) dengan hilir (ibu kota kerajaan). Daerah pedalaman yang dimaksud adalah daerah yang berada di hulu Sungai Batanghari. Kedua, lada dari hulu tidak dibawa ke hilir melainkan dibawa melalui jalur alternatif, yaitu dari hulu ke Muaro Tebo kemudian dibawa ke Selat Malaka melalui Indragiri dan Kuala Tungkal.

Gusti Asnan dalam bukunya Sejarah Sumatra menjelaskan, petani lada di hulu memilih pasar Muaro Tebo yang saat itu juga pusat perdagangan penting di daerah hulu. Muaro Tebo memiliki akses jaringan transportasi ke Indragiri dan Kuala Tungkal melalui Sungai Sumai dan dilanjutkan dengan jalan setapak menembus hutan. Cara ini merupakan bentuk ketidakpatuhan dari masyarakat hulu sungai terhadap pusat pemerintahan di bagian hilir. Ketidakpatuhan dilakukan dengan tidak melakukan kontak langsung dengan pusat pemerintahan. Tegasnya, penghindaran dilakukan dengan tidak melintasi perairan yang melewati ibu kota kerajaan. Tindakan menghindar dari kontrol penguasa adalah dengan cara pindah sungai. Sebagai contoh, penduduk atau saudagar yang berasal dari hulu sungai Batang Hari menghindari pusat Kesultanan Jambi dengan menggunakan jalan setapak untuk pindah ke sungai lain untuk menghindari hegemoni penguasa (Asnan, 2016: 87). Perlawanan melalui pindah sungai adalah sebuah gambaran 
realitas yang mengisi lembaran sejarah masyarakat Sungai Batang Hari. Perlawanan seperti itu menjadi pola tersendiri dalam sejarah sosial dan politik daerah bagian tengah dan sebagian kawasan selatan Pantai Timur Sumatra.

Pada musim kemarau saat perdagangan dengan Pelabuhan Jambi terhenti, Muaro Tebo berperan menjadi pelabuhan transit bagi produk lada dari daerah Minangkabau dan dari daerah Tanjung, Kuamang, dan Sumai. Muaro Tebo begitu ramai karena barangbarang dagangan berupa tekstil dan garam dibawa orang Melayu dari Kuala Tungkal. Kedekatannya dengan jaringan perdagangan Melayu di Selat Melaka maka kadang-kadang Muaro Tebo disebut Melaka Kecil (Lindayanti, et al., 2013: 73).

Selain itu, lada dari daerah Jambi, Palembang, Indragiri, Siak, Kampar dan Rokan yang pernah menjadi daerah koloni Malaka juga dibawa dan diperdagangkan di Malaka. Oleh karena itu, terciptalah jaringan perdagangan antara daerah-daerah itu dengan Malaka, termasuk halnya Jambi (Lindayanti, et al., 2013: 79).

\subsection{Perkembangan Perdagangan \\ Lada}

Perdagangan lada di Jambi berkembang bersama komoditas ekspor-impor lainnya. Tahun 1710 , ekspor Jambi masih sepenuhnya terdiri atas lada. Tahun 1730, lebih dari setengah produk ekspor terdiri atas emas. Tahun 1750, ekspor lada mencapai 80 persen lebih (Lindayanti, et al., 2013: 76).

Meningkatnya perdagangan, sebagaimana yang telah disebutkan sebelumnya, membuat lada juga berfungsi sebagai alat tukar sekitar abad XVI hingga awal XVII.

Penggunaan lada sebagai alat tukar membuat transaksi perdagangan lada di Jambi berkembang dalam dua bentuk, yakni sistem barter dan sistem tunai.

Adapun salah satu kelompok yang menjadikan lada sebagai alat tukar adalah pedagang Portugis. Mereka yang aktif berdagang di Pelabuhan Jambi pada akhir abad XVI dan awal abad XVII membawa kain-kain ke Jambi tidak saja untuk dijual tetapi juga untuk ditukar dengan lada.

Pedagang Portugis diuntungkan karena kain yang dibawanya menjadi barang dagang populer sehingga laku ditukar dengan lada. Saking diminati, syahbandar Jambi tidak menarik cukai impor kain di Jambi. Meskipun demikian, mereka akan tetap dikenakan cukai sebesar 10 persen dari harga lada yang diekspor (Lindayanti, et al., 2013: 72).

Para pedagang Portugis memanfaatkan masa panen lada di Jambi, termasuk pada akhir abad XVI-XVII yang mencapai 40.000 sampai 50.000 karung per tahun dengan bobot 50 pon per karung. Mereka mengejar keuntungan dari momen tersebut hingga mendatangi daerah hulu menggunakan kapal-kapal kecil untuk membeli lada (Roelofsz, 2016: 226). Perdagangan lada dengan sistem barter 
memang terjadi di daerah hulu Jambi. Dengan demikian, pedagang Portugis memeroleh lada, sementara petani lada mendapatkan garam, tekstil atau barang dagangan lain (Lindayanti, et al., 2013: 72).

Selain pedagang Portugis, pedagang Cina juga memiliki cara yang sama. Agen-agen atau pedagang Cina datang ke hulu membawa tekstil dan melakukan barter dengan petani lada. Petani lada juga senang memeroleh tekstil karena bisa kembali menjualnya di kampungnya (Lindayanti, et al., 2013: 72).

Transaksi tunai di Jambi tampaknya menggunakan uang picis Jambi yang beredar di Jambi abad XVII. Nilainya fluktuaktif dengan mata uang real yang digunakan dalam perdagangan internasional. Tahun 1619 , nilai satu real sama dengan 8.500 picis. Tahun 1636 , satu real nilainya 6.900 uang picis (Lindayanti, et al., 2013: 72). Menurut Lindayanti, situasi ini tidak menguntungkan petani. Lada dibeli dengan uang picis, namun harga lada ditentukan berdasarkan nilai real. Pada awalnya picis dibawa para pedagang Cina. Namun, untuk mengatasi fluktuasi nilai picis, Kesultanan Jambi mencetak sendiri uang picis tersebut.

Harga lada dalam beberapa tahun, tahun 1599 hingga 1621 awalnya terjadi kenaikan harga yang luar biasa. Namun, setelah tahun 1603 terjadi penurunan harga. Penurunan harga terjadi karena pedagang Eropa berupaya menurunkan harga. Pedagang Eropa seperti Belanda dan Inggris kompak dalam menurunkan harga lada dan dilakukan di sejumlah pelabuhan. Pedagang Belanda dan Inggris menetapkan harga sesuai kemauan mereka sendiri. Pedagang Cina berupaya menerobos kebijakan itu dan mendapat perlawanan dari Belanda dan Inggris (Roelofsz, 2016: 404).

\begin{tabular}{|c|l|l|}
\hline Tahun & \multicolumn{1}{|c|}{ Satuan } & \multicolumn{1}{|c|}{ Harga } \\
\hline 1599 & Karung & 3 real \\
1600 & Karung & $4-6$ real \\
1608 & Karung & 21 real \\
1612 & Per 10 Karung & 121 real \\
1614 & Per 10 karung & 15 real \\
1616 & Per 10 karung & 17 real \\
1617 & Per 10 karung & 31 real \\
1618 & Per 2 karung & 10 real \\
\hline 1619 & Per karung & 2 real \\
\hline 1620 & Per 10 karung & 5 sampai 7,5 \\
\hline & & Real \\
\hline & & \\
\hline
\end{tabular}

Tabel 1. Tabel Harga Lada Sumber: Roelofsz, 2016: 402.

Tahun 1640, Kesultanan Jambi mengirim 100.000 picis ke daerah hulu untuk memperkenalkan uang tersebut. Tahun 1642, dicetak picis yang lebih berat dan menghapus picis berukuran ringan. Permasalahan timbul pada tahun 1645 saat muncul uang perak dari Batavia yang banyak kandungan tembaganya. Bentuk mata uang yang berubah-ubah pada abad XVII berdampak menimbulkan ketidakpercayaan petani di hulu terhadap pedagang yang datang dari hilir (Lindayanti, et al, 2013: 72).

Perkembangan perdagangan lada di Jambi pada abad ke-17 telah memberi pengaruh sosial-ekonomi terhadap penduduk Jambi dan sekitarnya. 
Pertama, meningkatkan jumlah petani lada.Banyak masyarakat berlombalomba menanam lada ini. Kedua, terciptanya jaringan perdagangan lada di sekitar Jambi. Sejumlah lada diekspor ke pantai timur dari Minangkabau melalui Jambi tahun 1623 sebesar 2.000 ton lada (50 ribu karung). Daerah rantau timur, seperti Kuamang, Tembesi dan Tanjung di sebelah utara Jambi pun menjadi daerah penghasil lada dalam jumlah besar. Ketiga, mendorong mobilitas penduduk dari berbagai daerah. Orang Laut yang datang dari Timur (kelompok orang Bugis), Orang Melayu Timur yang berasal dari Luzon, orang Jawa, orang Cina, dan orang Minangkabau. Kedatangan orang Jawa yang terutama bekerja sebagai pedagang lada di Jambi ditempatkan seorang gubernur wakil dari penguasa Jawa (Lindayanti, et al., 2009: 7).

\section{Pemain Lada di Jambi}

Para peserta perdagangan lada di Jambi dapat dibagi dalam beberapa kelompok. Kelompok pertama adalah penghasil lada atau petani. Kelompok kedua adalah para pedagang lada yang terdiri atas orang asing dan juga pihak kesultanan dan bangsawan Jambi.

\subsection{Petani Lada Minangkabau}

Produsen utama lada yang diperdagangkan di Jambi adalah orang Minangkabau yang tinggal di sepanjang hulu Sungai Batanghari, terutama di dua distrik, yakni Tanjung dan Kuamang. Saat harga lada bagus, penanaman lada diperluas (Andaya, 2016: 89). Lada kemudian ditanam di daerah Muaro Ketalo hingga Muara Tembesi.

Petani Minangkabau berkontribusi dalam penanaman lada yang membutuhkan tenaga kerja yang banyak. Tenaga kerja juga dibutuhkan untuk perawatan intensif pertanian lada agar hasil panennya bagus. Di hilir, lada ditanam tidak terlalu dekat dengan sungai karena bisa terdampak banjir. Lada dalam waktu empat tahun sejak ditanam sudah bisa dipanen dan bisa bertahan sampai umur 30 tahun (Lindayanti, 2013: 70).

Tidak hanya menjadi petani, petani lada termasuk orang Minangkabau juga terlibat langsung dalam perdagangan lada. Ada di antara mereka yang langsung menjual ladanya ke hilir, yakni Pelabuhan Jambi. Ada juga dari mereka yang menunggu pembeli datang, baik itu pedagang Portugis, Cina atau pedagang lain. Para petani lada dari hulu muncul di Pelabuhan Jambi sekitar akhir Maret dan awal April. Mereka kembali muncul di hilir Jambi antara bulan November dan Desember. Para petani membawa lada ke hilir menggunakan rakit dengan kapasitas muatan sebesar 150 pikul setiap rakit. Setiap tahunnya pada periode sekitar 40.000-50.000 karung lada dari dataran tinggi atau hulu Jambi dibawa oleh para petani ke Pelabuhan Jambi di hilir (Andaya, 2016: 89).

\subsection{Portugis}

Pada abad XVI, impor lada Eropa meningkat pesat. Pada tahun 1500 , 
impor mencapai kira-kira 1200 ton per tahun. Keinginan untuk mendominasi pasar menjadi pemicu Portugis untuk ekspansi ke Asia. Sebagian besar lada yang dimiliki Portugis pada abad XVI berasal dari arah barat daya India, namun Portugis tetap mendekati daerah penghasil lada di Sumatra dan Jawa. Portugis bisa mengendalikan jumlah pasokan lada ke Eropa agar tetap berada lebih rendah dari tingkat permintaan (Andaya, 2016: 83).

Tahun 1509 sebelum mengambil alih Malaka, Portugis sudah masuk ke daerah Pedir dan Pasai di Aceh. Di sana, Portugis mendirikan padrao, sebuah salib marmer yang berfungsi untuk menunjukkan penemuan dan kepemilikan. Namun, penetrasi Portugis di Aceh tidak bisa bertahan lama. Tahun 1524, Portugis diusir dari Aceh. Dengan kondisi ini, Portugis sangat bergantung pada pasokan lada dari Jambi. Selain dari Jambi, Portugis juga bergantung pada pasokan lada dari Sunda. Sepanjang abad XVI, kebijakan monopoli Portugis mampu harga lada tetap tinggi di Eropa. Sepanjang 1592, harga lada 14 persen lebih tinggi dari seabad sebelumnya (Andaya, 2016: 83).

Sebagaimana yang telah disampaikan sebelumnya,akhir abad XVI hingga awal abad XVII, Portugis membeli lada menggunakan kapal-kapal kecil. Mereka langsung ke daerah hulu kala petani lada mengalami masa panen untuk ditukar dengan komoditas yang mereka bawa (Roelofsz, 2016: 226).

Andaya menulis, di mata orang Portugis, Jambi telah dikenal sebagai penghasil lada sejak tahun 1545. Pada 1568, Portugis menyebutkan daerah ini dalam instruksi untuk gagasan baru guna meningkatkan akses Portugis terhadap persediaan lada. Pada paruh akhir abad XVI, Jambi mulai banyak dipikirkan oleh Portugis karena permusuhan dengan Belanda di Banten semakin kuat. Gagasan tersebut sempat diragukan karena Portugis menilai bahwa lada di Jambi masih membutuhkan beberapa waktu untuk berkembang. Keraguan tersebut dipicu oleh volume hasil lada Jambi. Meskipun demikian, memasuki awal abad XVII, pedagang Portugis dari Malaka lebih sering mengunjungi Jambi. Sejak itu, mereka berupaya membangun langsung hubungan dagang ke pusat Jambi. Pasalnya, Jambi saat itu tidak dikuasai Aceh maupun Banten (Andaya, 2016: 85).

Untuk dapat menguasai perdagangan lada di Jambi, Portugis enggan membeberkan mengenai Jambi sebagai salah satu daerah pusat perdagangan lada ke bangsa Eropa lainnya. Tertutupnya informasi mengenai potensi perdagangan lada di Jambi ini didukung dengan kondisi alam. Kondisi Selat Malaka bagian selatan yang merupakan akses menuju Jambi adalah kuburan bagi kapal-kapal bangsa Eropa.

\subsection{Orang Cina}

Pedagang Cina dapat dikatakan merupakan pemain paling kuat dalam perdagangan lada di Jambi. Kuatnya posisi dagang mereka setidaknya dapat 
dilihat dari dua hal, yakni volume ekspor yang diangkut oleh para pedagang Cina dan relasi dagang yang dibangun.

Volume ekspor tergambar pada sekitar tahun 1615, 2 atau 3 jung besar dari Cina datang ke Jambi setiap tahun. Pedagang Cina membeli 5.500 pikul lada dan menukarkannya dengan barang Cina, seperti kain sutra, kancing baju, tembikar, dan obat-obatan (Lindayanti, et al., 2013: 67). Relasi para pedagang Cina di Jambi terjalin dengan berbagai kelompok etnik dan kelas sosial. Luasnya relasi yang mereka bangun disebabkan oleh perilaku dagang (ekonomi) dan sosial. Relasi pedagang Cina dengan masyarakat dan Kerajaan Jambi lebih diterima disebabkan oleh tiga faktor. Pertama, orang Cina dapat diterima oleh orang setempat karena mereka menikah dengan wanita lokal. Perkawinan ini menguntungkan kedua belah pihak. Pedagang Cina suka kawin campur karena nantinya bisa lebih meningkatkan kekuasaan dan diterima masyarakat lokal. Di sisi lain, perempuan lokal yang menikah dengan pedagang Cina dapat mengubah nasib mereka secara ekonomi dan meningkatkan status sosial (Andaya, 2016: 97).

Kedua, pedagang Cina terbuka terhadap Islam dan banyak di antara mereka yang mualaf. Beberapa pedagang Cina yang datang ke Jambi juga hasil peranakan Arab-Cina. Ada pula penerjemah di Jambi yang lahir dari orang tua Cina dan perempuan lokal. Ia adalah saudara saudagar Jepara dan juga memiliki hubungan kerabat dengan Kapitan Cina pertama yang ditunjuk bertugas di Batavia (Roelofsz, 2016: 259). Selain itu, orang Cina yang dipercaya sebagai syahbandar di Pelabuhan Jambi juga beragama Islam (Andaya, 2016: 98).

Faktor tambahan, selain bertindak sebagai agen di daerah hilir, orang Cina juga membangun tempat tinggal di daerah penghasil lada, seperti Kuamang dan Tembesi. Pedagang ini diterima masyarakat dan hidup berdampingan. Di hulu, mereka juga menjual kain yang bisa ditukar dengan lada. Pedagang Cina itu juga memberikan dana sebagai utang kepada petani lada. Setelah panen, lada dijual kepada pedagang Cina itu.

Relasi pedagang Cina juga dapat dijalin dengan pedagang lada dari etnik lain di Nusantara dan pedagang asing lain. Pedagang Cina dipilih oleh para pedagang Jawa yang membeli lada di Jambi untuk kemudian dijual di pelabuhan-pelabuhan di Jawa. Pedagang Cina juga dipilih oleh pedagang Portugis Saudagar Cina dan Portugis meminta perlindungan kepada penguasa setempat untuk berdagang lada. Portugis juga membeli barang dagang saudagar Cina. Cina dan Portugis di Jambi tidak bermusuhan. Saat Belanda datang, Portugis dan Cina menjadi lawan mereka. Sesepuh penguasa Jambi dan bangsawan Jambi lebih memihak Portugis saat konflik dengan Belanda. Kedatangan Inggris menjadikan, pertarungan melawan 
Portugis lebih sengit dalam monopoli lada (Andaya, 2016: 102).

Pedagang Cina bahkan sempat digunakan oleh Belanda dalam perdagangan lada di Jambi meski secara umum pedagang Belanda dan Cina bermusuhan. Hal ini ditunjukkan oleh kiprah seorang pedagang perantara bernama Kecil Japon yang bergelar Orang Kaya Sirre Lela menjadi pedagang perantara antara sultan dan pedagang asing. Kecil Japon beragama Islam dan rambutnya dikuncir. Kecil Japon dihormati karena statusnya diangkat sebagai bangsawan Jambi oleh sultan (Lindayanti, et al., 2013: 68).

Faktor-faktor tersebutlah yang menguatkan posisi pedagang Cina di Jambi sehingga berani melawan Belanda dan Inggris. Mereka memiliki daya saing dalam menawar harga lada dengan harga yang diajukan pedagang Belanda dan Inggris Sebagai gambaran, pada tahun 1636, 15 pedagang Cina di Jambi mengekspor lada ke Cina yang nilai harganya 1.257 real, nilai yang lebih tinggi dari pedagang Belanda dan Inggris. Kekuatan pedagang Cina tersebut menyebabkan Belanda dan Inggris yang meski bersaing namun kompak melawan mereka dalam perdagangan lada di Jambi (Andaya, 2016: 102).

Walaupun orang Cina memainkan peranan begitu penting dalam perdagangan lada di Jambi, namun hanya sedikit individu yang memiliki modal besar dalam perdagangan lada di Jambi. Kekuatan modal tersebut salah satunya terlihat dari sedikitnya jumlah pedagang Cina yang mampu menyaingi penawaran harga lada pedagang Belanda dan Inggris yang tinggi

\subsection{Belanda dan Kontrak Perdagangan Lada}

Upaya Portugis mengendalikan jalur perdagangan lada di Jambi jauh dari Belanda berakhir dengan kegagalan. Pada tahun 1615, Jan Pieter Zoon Coen, Direktur Kantor Dagang Belanda (VOC) di Banten memerintahkan ekspansi perdagangan ke Jambi dengan mengirim satu kapal. Andries Soury ditugaskan untuk membuka jalur perdagangan lada di Jambi. Mereka diterima dengan baik di istana Jambi dan Belanda membangun kantor dagang di Jambi.

Tahun 1615, pedagang Belanda (VOC) baru menemukan jalan ke Pelabuhan Jambi bernama Tanah Pilih melalui Sungai Niur. Kondisi sungai penuh rawa dan belukar menyulitkan pedagang Belanda masuk. Tidak hanya Belanda, pedagang Inggris melalui EIC juga kesulitan menembus Pelabuhan Jambi. Perjalanan menemukan Jambi bukan hal mudah bagi pedagang Eropa. Kekalahan Portugis tahun 1630, menjadikan Belanda dan Inggris mendominasi perdagangan lada di Jambi. Kapal-kapal VOC berupaya mencegat jung-jung Cina yang akan berlayar ke Jambi. Tindakan ini untuk memonopoli lada dan bisa membeli dengan harga murah. Jambi pelabuhan penting dalam perdagangan lada. Jungjung Cina dan kapal dari Siam, Pattani, Jawa, Makkasar, dan Malaka bersandar 
di sana. Pada tahun 1613, tiga jung Cina merapat di sana dan saat itu tidak tersedia banyak lada sehingga hanya bisa mengangkut 11.000 karung lada. Lada-lada tersebut sudah termasuk lada dari daerah sekitar Jambi yang diekspor melalui Pelabuhan Jambi. Hal ini seperti yang terjadi pada tahun 1623 , hasil lada dari Minangkabau diekspor melalui Pelabuhan Jambi (Roelofsz, 2016: 422).

Di Jambi, Belanda bersaing ketat dengan pedagang Cina walau sesekali tidak bisa mengelak untuk tetap bekerjasama.Pedagang Cina pandai menarik simpati Kesultanan Jambi untuk lepas dari cukai ekspor lada karena mereka berencana akan datang dalam enam atau tujuh jung Cina untuk membeli lada Cina menawarkan cara membuat senjata api untuk pihak kerajaan dalam bisnis lada ini. Belanda pun bahkan memanfaatkan kelihaian pedagang Cina untuk memengaruhi Kesultanan dengan menggunakan pedagang perantara bernama Ketjil Japon, orang Cina mualaf. Belanda juga memanfaatkan peminjaman jung dari pedagang perantara untuk mengangkut lada dari Jambi ke Batavia. Belanda dan Inggris juga berhubungan dengan beberapa pedagang perantara lain selain Ketjil Japon yang juga etnis Tionghoa muslim (Andaya dalam Arman, 2017: 61).

Dalam perdagangan lada di Jambi, Belanda juga bekerjasama dengan Inggris seperti halnya kesepakatan yang dibuat pada tahun 1620. Mereka bersepakat menentukan harga lada tidak boleh lebih dari 4 real per karung. Kedua belah pihak tidak selamanya bisa bekerjasama dan malah terlibat persaingan memonopoli lada. Pihak Kesultanan Jambi tidak nyaman dengan cara monopoli Belanda dan Inggris karena menyebabkan pedagang lain enggan datang ke Jambi. Tahun 1620, tidak ada satu pun kapal Cina yang datang ke Pelabuhan Jambi. Belanda memaksa kapal-kapal Cina berlayar ke Batavia (Andaya dalam Arman, 2017: 61).

Belanda banyak melakukan kontrak dagang dengan penguasa Jambi. Tanggal Kontrak 6 Juli 1643 antara Pangeran Anom dengan VOC yang diwakili oleh Pieter Soury mengenai lada menyebutkan bahwa, budak-budak kompeni boleh tinggal dan berdangang di Jambi, demikian pula rakyat Jambi boleh berdagang dan tinggal di Batavia. Ada juga kontrak tertanggal 12 Juli 1681 antara Sultan Jambi dengan VOC yang diwakili oleh Adrian Wiland. Dalam kontrak ini, kompeni memberikan perlindungan kepada Kesultanan Jambi jika mendapat ancaman dari Palembang. Sebagai kontrak imbalannya, harga lada yang dijual kepada kompeni diturunkan sama dengan harga lada yang dibeli kompeni dari Palembang. Di samping itu, kompeni mendapatkan monopoli impor kain linen

Kontrak 11 Agustus 1683 antara Sultan Ingalaga dengan VOC menyebutkan kompeni memeroleh monopoli pembelian lada, impor kain, dan opium (candu) di Jambi. Sultan 
Jambi dan para penggantinya, termasuk para pembesar kerajaan lainnya harus melarang orang asing lainnya membawa dan menjual kain di wilayah Kerajaan Jambi, dan jika hal itu terjadi maka kapal dan barang bawaannya dirampas, sebahagian diserahkan kepada sultan dan sebahagian diserahkan kepada VOC.

Kontrak 21 Agustus 1681 antara Sultan Anom dengan VOC berisi keterangan tentang hak kompeni untuk memeroleh monopoli pembelian lada di Jambi. Setiap akhir tahun sultan Jambi diharuskan memasok 1000 pikul lada dengan harga setiap pikul 4-5 real. Jika ada orang Jambi menjual lada kepada selain VOC, baik itu pejabat, pembesar kerajaan atau rakyat biasa, bila ketahuan ladanya dirampas, separuh diserahkan kepada sultan dan separohnya lagi kepada kompeni (ANRI, 2006: 12).

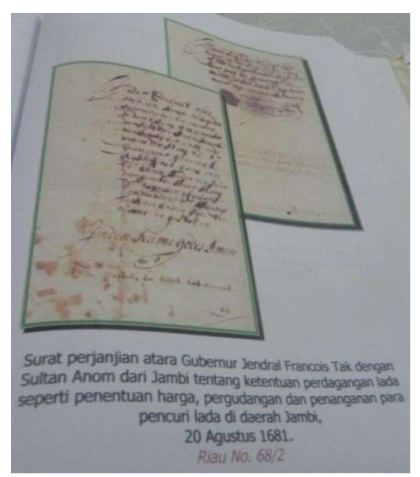

Gambar 3. Perjanjian Gubernur Belanda dan Sultan Anom.

Sumber: ANRI, 2006: 12.

Kontrak 20 Agustus 1683 antara sultan Jambi dengan VOC tentang pembaharuan kontrak 6 Juli 1643 antara Pangeran Dipati Anom dengan komisaris Pieter Soury mengenai perdagangan lada. Catatan kontrak ini ada dalam arsip yang tersimpan di Arsip Nasional Republik Indonesia.

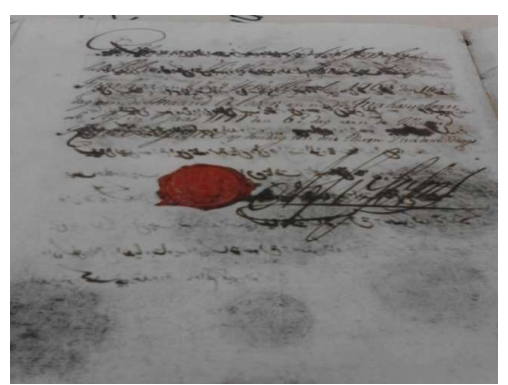

Gambar 4. Kontrak Perdagangan Lada Pangeran Dipati Anom dan Pieter Soury. Sumber: ANRI, Inventaris Arsip Riouw 68/7.

Kontrak 21 Oktober 1721 antara Sultan Astra Ingalaga dengan VOC (isinya tidak dapat dibaca lagi karena arsipnya rusak). Akta perjanjian 12 Juni 1756 antara Sultan Ingalaga dengan VOC berisi kebebasan kepada kompeni untuk berdagang di Jambi. Sultan Jambi juga harus menunjuk saudagar yang membeli barang-barang kompeni. Kontrak 16 Oktober 1763 berisi upaya memperkuat perjanjian-perjanjian yang dibuat sebelumnya yakni: (a) Jambi di bawah perlindungan kompeni; (b) Orang-orang Cina dan pedagangpedagang yang diam dan menetap di Muara Jambi membantu pekerjaan kompeni; (c) Kebun lada yang rusak agar direhabilitasi dan ditanami kembali dan tidak boleh diberikan selain kepada kompeni. Isi kontrak di atas menunjukkan bahwa kekuatan militer memberikan kekuasaan besar kepada VOC yang notabene hanya sebuah perusahaan untuk mengendalikan keputusan-keputusan kerajaan (Siagian, 2008: 1). 
Tidak hanya antara VOC dan Kesultanan, juga ada perjanjian antara kantor dagang Inggris (EIC) dan pembesar VOC Belanda tentang penentuan harga lada. Ada surat persetujuan antara Deputi Inggris dan pembesar Belanda di Jambi tentang harga terendah lada yang dibawa keluar Jambi tertanggal 25 Oktober 1621.

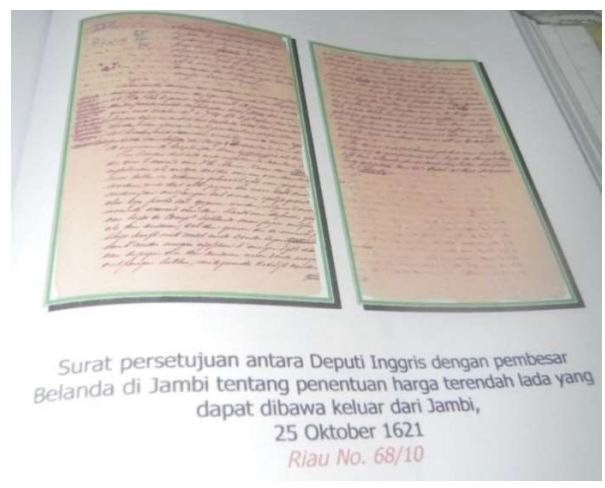

Gambar 5. Surat persetujuan harga terendah lada Inggris dan Belanda. Sumber: ANRI, 2006.

\section{Kemunduran Lada Jambi}

Kejayaan perdagangan lada di Jambi tidak lama. Akhir abad ke-17, keseganan untuk menanam lada sangat jelas muncul dalam tulisan-tulisan Melayu. Hal ini menimbulkan kekhawatiran elite istana yang terancam oleh tidak stabilnya penanaman lada.

Dalam sejumlah sumber, seperti Andaya dan Lindayanti, ada sejumlah faktor yang menyebabkan perdagangan lada di Jambi mengalami kemunduran. Yakni, turunnya harga lada di pasaran Eropa menyebabkan penurunan penanaman lada. Petani di daerah hulu enggan menanam lada. Selain itu, daerah hulu yang jauh dari pusat kekuasaan kesultanan enggan adanya monopoli perdagangan lada yang menyebabkan harga lada dibeli dengan murah. Petani di hulu Jambi mengalihkan tanamannya dari lada ke tanaman lain, seperti kapas dan padi. Selain itu memiliki mata pencaharian lain, yakni mencari emas dengan adanya pertambangan emas rakyat.

Kondisi di Jambi berbeda dengan daerah penghasil lada lain di Sumatra, seperti Bangka Belitung, Lampung, dan Palembang. Di daerah Bangka Belitung tanaman lada dianggap tanaman kultural. Saat harga lada anjlok, petani lada membiarkan tanaman lada tidak terawat. Petani menggantungkan hidupnya dari sektor pertanian lain. Saat harga lada harganya kembali bagus, petani kembali membersihkan tanaman ladanya dan kembali dikelola. Lada berkali-kali menjadi penyeimbang perekonomian di Bangka saat krisis melanda. Lada menjaga perekonomian Bangka tetap bergerak saat krisis pada awal abad XX yang dikenal sebagai masa malaise. Begitu juga saat krisis 1997 lalu, perekonomian Bangka tetap hidup karena harga lada yang mahal (bangka.tribunnews.com, diakses pada 17 Juni 2012)

Tahun 1680, Jambi kehilangan posisinya sebagai pelabuhan lada utama di pesisir timur Sumatra setelah bentrok dengan Johor. Hal ini diperparah pergolakan internal. Dalam bidang perdagangan, terjadi ketegangan antara hulu dan hilir yang fungsinya antara produsen dan perantara. Inggris meninggalkan pos dagangnya di Jambi tahun 1679. VOC bertahan agak lama 
meski kongsinya mendatangkan untung yang kecil setelah tahun 1680 .

Ketika terjadi permasalahan perekonomian VOC melakukan campur tangan lebih aktif. Sultan ditangkap dan dibuang ke Batavia. Aksi ini menjadikan Jambi terbelah antara hulu dan hilir. Perekonomian Jambi semakin memburuk tahun 1720. Di dataran tinggi, masyarakatnya beralih menanam kapas dan padi. Petani meninggalkan penanaman lada karena harganya yang terus anjlok. Hal ini dampak membanjirnya pasokan lada ke Eropa yang berimbas terjadinya penurunan harga.

Istana atau pihak Kesultanan Jambi sangat merasakan dampak penurunan perdagangan lada di Jambi. Selama ini sultan dan bangsawan Jambi terlibat dalam bisnis lada. Dalam permodalan, mereka banyak meminjam modal dari Belanda. Saat pasokan lada terhenti, kondisi ini menyebabkan mereka terlibat masalah yang besar. Tahun 1700, pundi-pundi keuangan sultan kosong dan pusaka istana dijadikan agunan. Pada akhir abad XVIII, Kesultanan Jambi menjadi negara vassal dibawah Raja Minangkabau di Pagaruyung (Scholten, 2008: 42).

Orang Minangkabau yang melakukan perpindahan besar-besaran abad XVII menjadi berkuasa dan menguasai daerah dataran tinggi. Jambi hulu menjadi daerah Minangkabau. Tahun 1768, orang Jambi menyerang pos dagang VOC. Akhirnya VOC menutup pos dagangnya di Jambi. Perdagangan Jambi tidak mendatang- kan banyak hasil. Pada akhir abad XVIII, lada Jambi dianggap bermutu rendah. Pada abad XIX, pedagang Nusantara tidak lagi berlabuh di Jambi (Scholten, 2008: 45).

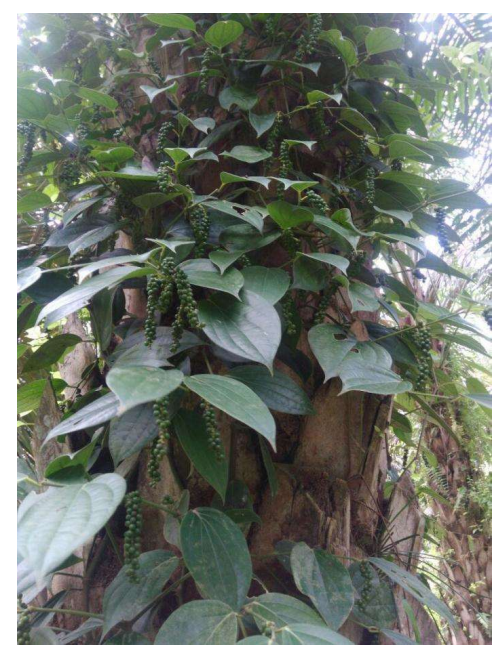

Gambar 4. Lada ditanam di lahan kelapa sawit.

Sumber: https://indonesiana.tempo.co 10 Januari 2017.

Perdagangan lada sendiri diyakini tidak membawa kemakmuran panjang bagi masyarakat. Malahan tanaman lada dianggap bisa menimbulkan konflik karena hawanya yang panas dan banyak kalangan yang ingin memonopoli. Anthony Reid mengutip Hikayat Kerajaan Banjarmasin yang mengeluhkan kondisi dampak tanaman lada.

"Biarkan tidak seorang pun di negeri menanam lada, sebagaimana hal itu tidak dilakukan di Jambi dan Palembang. Mungkin negeri-negeri itu menanamnya demi uang agar bisa merengkuh kekayaan. Tidak diragukan lagi bahwa mereka akan tiba pada saat keruntuhannya. Yang didapat hanya perseteruan dan bahan 
pangan akan menjadi mahal... Peraturan peraturan akan berada dalam kekacauan karena orang di kota raja tidak akan dihormati oleh penduduk pedesaan; pengawalpengawal raja tidak akan ditakuti oleh orang pedesaan. Jika lebih banyak (lada ditanam melebihi kebutuhan rumahtangga) ditanam, demi menggapai uang, bencanalah yang menyelemuti negeri. Perintah dari kerajaan akan diabaikan karena orang-orang berani menentang raja (Reid,1999: 347)."

Setelah dua abad menghilang, barulah tahun 2016 lalu, penanaman lada kembali dilakukan di Jambi. Petani di Kabupaten Tanjung Jabung Barat membudidayakan lagi, tapi ditanaman di lahan gambut (Kompas, 12 September 2016). Kelompok Tani Senang Jaya di Sungai Beras, Kecamatan Mendahara Hulu menanam 1100 bibit lada. Sifatnya baru penanaman dan lada belum ada yang dipanen.

Penanaman lada pola tumpang sari dilakukan petani di Kabupaten Batanghari, Jambi. Petani menanam lada di antara kelapa sawit. Lada merambat di batang kelapa sawit. Namun, penanaman juga masih sebatas ujicoba dan belum skala besar.

Instansi terkait di Jambi juga menilai peluang menghidupkan kejayaan lada Jambi. Menurut Kepala Dinas Pariwisata Kebudayaan Provinsi Jambi, Ujang Hariadi tidak hanya sisi pertanian dan perkebunan, jalur rempah di Jambi masa lampau menarik untuk diselusuri. Jalur transportasi sungai dari hulu Sungai Batanghari ke hilir menarik untuk daya tarik wisata (Wawancara Ujang Hariadi, Jambi, 15 Mei 2017).

\section{PENUTUP}

Jambi pernah mengalami masa kejayaan dalam perdagangan lada pada abad XVI hingga XVIII meski di akhir abad XVII mulai mengalami penurunan. Pelabuhan Jambi pernah menjadi pelabuhan ekspor kedua terbesar setelah Aceh. Di Jambi, lada dihasilkan di daerah hulu, yakni daerah Tanjung dan Kuamang, federasi Kota Tujuh (VII Koto) dan Sembilan Kota (IX Koto). Ada dua pola perdagangan lada di Jambi. Pertama, pola perdagangan lada dari daerah produksi di hulu dibawa ke hilir (Pelabuhan Jambi). Pola kedua, lada dari hulu tidak dibawa ke hilir melainkan dibawa melalui jalur alternatif. Dari hulu dibawa ke Muaro Tebo yang nantinya dibawa ke Selat Malaka melalui Indragiri dan Kuala Tungkal.

Pihak asing banyak yang terlibat dalam perdagangan lada di Jambi, mulai dari Portugis, Cina, Belanda dan Inggris. Tidak hanya orang asing, sultan dan bangsawan Jambi juga ikut berdagang lada. Masa kejayaan perdagangan lada Jambi tidak bertahan lama seiring melorotnya harga lada di pasaran Eropa. Dampaknya adalah petani lada di Jambi enggan menanam lada dan beralih menanam kapas dan kapas. Akibat kemunduran perdagangan lada berpengaruh besar pada perekonomian Jambi yang memburuk 
tahun 1720. Kesultanan Jambi mengalami kebangkrutan. Sultan Jambi terlibat utang pada Belanda. Dalam perdagangan lada, sultan dan bangsawan Jambi meminjam modal berdagang dari Belanda. Kesultanan Jambi akhir abad XVIII menjadi daerah vassal (taklukan) Minangkabau.

Sejak akhir abad XVIII hingga kini, lada menghilang di Jambi. Hingga saat ini jejak kebesaran perdagangan lada di Jambi tidak ditemukan lagi. Barulah beberapa tahun terakhir ada upaya penanaman lada di daerah Tanjung Jabung Timur. Itu pun sifatnya lada ditanam di lahan gambut dan dalam skala kecil. Pemerintah Provinsi Jambi juga belum terlihat menggalakkan kembali perdagangan lada yang pernah jaya di masa lampau.

Ada sejumlah masukan dan saran terkait penelitian perdagangan lada di Jambi. Penelitian perdagangan lada di Jambi aspek yang belum disentuh. Belum ada kajian yang utuh membahas sejarah perdagangan lada di Jambi. Kondisinya berbeda dengan perdagangan lada di Bangka Belitung, Palembang dan Lampung yang cukup banyak jadi perhatian dan diteliti. Terbuka sekali kesempatan untuk menulis perdagangan lada di Jambi dari aspek arkeologi, antropologi selain aspek kesejarahan.

Tidak hanya melakukan penelitian, Pemerintah Provinsi Jambi melalui Dinas Kebudayaan dan Pariwisata Jambi bisa melakukan napak tilas atau menggelar ekspedisi jalur rempah Jambi. Ini sangat menarik karena akan membuka potensi wisata baru di Jambi yang harus diakui tidak banyak memiliki potensi wisata dibandingkan provinsi tetangga, seperti misalnya Sumatra Barat. Pemerintah Provinsi Jambi bisa menggerakkan masyarakatnya yang sebenarnya telah memiliki pengetahuan dan keterampilan dari leluhurnya untuk menanam lada. Kondisi tanah Jambi khususnya di daerah hulu sangat cocok untuk tanaman lada. Komoditas ini juga sangat menjanjikan karena harganya relatif bagus dan tanaman ekspor yang dibutuhkan banyak negara. Dengan demikian, komoditas pertanian rakyat ini dapat meningkatkan daya beli petani sebagaimana yang telah terbukti di masa lampau yang mana petani lada mampu memiliki kain dan tekstil impor.

\section{DAFTAR SUMBER}

Andaya, Barbara Watson. 2016. Hidup Bersaudara di Sumatra Tenggara Abad XVII dan XVIII. Yogyakarta: Penerbit Ombak.

Arman, Dedi, Telisik Perdagangan Lada di Jambi Abad XVI-XVIII, diunduh dari http:/kajanglako.com/ id-235-post-telisik-perdaganganlada-di- jambi-abad-xvixviii.html, pada September 2017.

.2017. Dari Hulu ke Hilir Batanghari:Aktivitas Perdagangan Lada di Jambi Abad XVI-XVIII). 
Tanjungpinang:Balai Pelestarian

Nilai Budaya Kepri.

Arsip Nasional Republik Indonesia, Inventaris Arsip Riouw No. 68/7.

Arsip Nasional Republik Indonesia. 2006. Citra Jambi Dalam Arsip. Jakarta: Arsip Nasional Republik Indonesia.

Asnan,Gusti 2016. Su n g a $i$ \& Sejarah Sumatra. Yogyakarta: Ombak. 2017. Jaringan Pelayaran dan Perdagangan Rempah di Pulau Sumatera. Makassar: Makalah Seminar Digelar Balai Pelestarian Nilai Budaya Sulawesi Selatan tanggal 12 Agustus di Makassar.

http://bangka.tribunnews.com, diakses pada 17 Juni 2012.

http://jalurrempah.com, diakses pada 14 September 2017.

https://indonesiana.tempo.co, diakses 10 Januari 2017.

Imadudin, Iim. 2016. Perdagangan Lada di Lampung Dalam Tiga Masa (1653-1930). Patanjala Vol. 8 No. 3 September 2016, hlm. 349-364. Kompas. 2016. "Budidaya Lada di Jambi Kembali Dihidupkan," 24 September 2016.
Kompas. 2017. "Bonggol-Bonggol Tua Penanda Sejarah," 19 Juli, hlm.12.

Lindayanti, T. Noor, Junaidi, dan Ujang Hariadi. 2013. Jambi Dalam Sejarah 1500-1942. Jambi: Pusat Kajian Pengembangan Sejarah dan Budaya Jambi.

Lindayanti, Witrianto, dan Ulqayyim. 2010. Harmoni Kehidupan di Provinsi Multi Etnis: Studi Kasus Integrasi Antara Penduduk Pendatang dan Penduduk Asli di Jambi. Padang: Laporan Penelitian Universitas Andalas.

Locher-Scholten, Elsbeth. 2008. Kesultanan Sumatra dan Negara Kolonial, Hubungan JambiBatavia (1830-1907) d a $n$ Bangkitnya Imperialisme Belanda. Jakarta: KITLV.

Marsden, William. 2013. Sejarah Sumatra. Jakarta: Komunitas Bambu.

Masroh, Laelatul. 2017. Perkebunan dan Perdagangan Lada di Lampung 1816-1942. Skripsi. Malang : Jurusan Sejarah Fakultas Ilmu Sosial Universitas Negeri Malang.

Reid, Anthony. 1999. A s $i$ a Tenggara Dalam Kurun Niaga 1450-1680. Jilid 2: Jaringan Perdagangan Global. Jakarta: Yayasan Obor. 
Roelofsz, Meilink M.A.P. 2016.

Perdagangan Asia \& Pengaruh Eropa di Nusantara Antara 1500 dan Sekitar 1630. Yogyakarta: Penerbit Ombak.

Siagian, Marahalim, Kontrak Dagang Kerajaan Melayu dengan VOC 1643-1763 diunduh dari http:// u g m . a c a d e m i a . e d u/ MarahalimSiagian, pada tanggal 19 Mei 2018.

Soedewo, Ery. 2007. Lada Si Emas Panas: Dampaknya bagi Kesultanan Aceh dan Kesultanan Banten, Historisme, Edisi 23 Tahun XI, hlm. 18.

Wawancara. Ujang Hariadi. Jambi, 15 Mei 2017

Wiwik, Swastiwi Anastasia. 2010. Jambi Dalam Lintasan Sejarah Melayu (Abad I-XVII). Tanjungpinang: Balai Kajian Sejarah dan Nilai Tradisional Tanjungpinang. 
